of its parallax. The mistake was a very easy one to make, but at least the Dunsink observations are not to blame, for Dr. Ball gives not only the place of the star he observed but its number in three catalogues-Groombridge, Struve's Mensurce, and the Durchmusterung.

BARNARD's Comet.-Dr. H. Oppenheim (Astr. Nackr.; No. 2697) has computed the following elements and ephemeris for this comet :--

Perihelion Passage $=I 886$ May $14^{\circ} 1430$ Berlin M.T.

$$
\begin{aligned}
& \omega=\text { ií } 3 \text { i } 57 \text { ) } \\
& \Omega=6622 \text { I } 2 \text { Mean Eq. } 1885^{\circ} \text { o } \\
& i=9487 \\
& \text { log. } q=9.74184
\end{aligned}
$$

Error of the middle observation :-

$$
\delta \lambda=+4^{\prime \prime} \quad \delta \beta=-3^{\prime \prime} .
$$

The elements resemble those of Comet 1785 II.

$$
\begin{aligned}
& \text { Ephemeris for Borlin Midnight } \\
& { }^{288} 5 \text { App. R.A. App. Decl. Log. } \Delta \text { Brightness }
\end{aligned}
$$

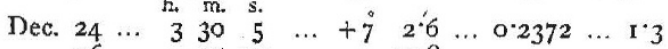

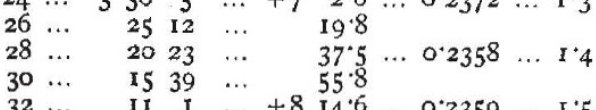

The brightness on December 5 is taken as unity.

The Pulkowa ObServatory. - From his Report, presented May 25, 1885, it appears that M. O. Struve was chiefly occupied, during the year to which the Report refers, with work connected with the erection of the great 30 -inch refractor. Various unexpected delays had occurred, in connection chiefly with the construction of the dome, but, at the time of writing his Report, M. Struve states that regular observations could be commenced immediately. He expresses himself as greatly pleased with the mounting of the instrument, which has been designed and constructed by the Repsolds. At present the dome is moved by hand, but it is hoped that this may eventually be done by electricity, and that motive power will thus be obtained sufficient to overcome the hindrance to the rotation of the dome caused by stow and frost. It is proposed to use the great refractor for observing such double-stars as are beyond the reach of the 15 -inch equatorial, and to undertake observations of interesting nebulæ, as well as spectroscopic researches in cases where the great optical power of the instrument will be of special importance. We learn from Science that M. Struve has written to Messrs. Alvan Clark and Sons, acknowledging the excellent performance of the object-glass furnished by them, and announcing that the Emperor of Russia had conferred on them the Honorary Gold Medal of the Empire.

Notwithstanding the additional cares and labours thus imposed on the staff of the Pulkowa Observatory, further increased by M. O. Struve's regrettable illness, the usual work in the various departments has been kept up with vigour, and it is evident that the famous Russian institution, under its present superintendent, will continue to maintain its great reputation.

Suspected "Nety" STaR.-It is announced in the Dun Echt Circular, No. 104, that Mr. Gore, observing with a binocular on the evening of December $\mathbf{I} 3$, found a reddish star of 6th mag., and about $2 \mathrm{O}^{\prime}$ following $\chi^{\prime}$ Orionis. This object is not given by Harding, Lalande, Heis, Birmingham, or the Bonn maps. On December 16 Copeland and Becker, observing at Dun Echt, found it of the $6 \frac{1}{2}$ mag., and of an orange-red colour. It has a very beautiful banded spectrum of the third type, seven dark bands being readily distinguished with the prism. The bright intervals seem full of bright lines, especially in the green and blue. The mean place for 1885 is R.A. 5 h. $48 \mathrm{~m}$. $59 \mathrm{~s}$. Decl. $+20^{\circ} 9^{\prime} \cdot 4$.

\section{ASTRONOMICAL PHENOMENA FOR THE}

WEEK 1885 DECEMBER 27-I886 FANUARY 2

(For the reckoning of time the civil day, commencing at Greenwich mean midnight, counting the hours on to 24 , is here employed.)

\section{At Greenwich on December 27}

Sun rises, $8 \mathrm{~h} .8 \mathrm{~m}$.; souths, I2h. Im. $27.7 \mathrm{~s}$.; sets, $15 \mathrm{~h} .55 \mathrm{~m}$. ; decl, on meridian, $23^{\circ} \mathrm{I} 9^{\prime} \mathrm{S}$. : Sidereal Time at Sunset, 22h. $20 \mathrm{~m}$.
Moon (at Last Quarter on Dec. 28) rises, 22h. $18 \mathrm{~m} .{ }^{*}$; souths, $4^{\mathrm{h}} .56 \mathrm{~m}$. ; sets, $1 \mathrm{Ih} .23 \mathrm{~m}$. ; decl. on meridian, $4^{\circ} 19^{\prime} \mathrm{N}$.

Planet Rises Souths Sets Decl.onmeridia

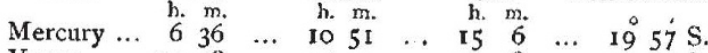

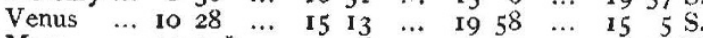

$\begin{array}{lllllllllllllllll}\text { Mars } & \ldots & 22 & 30^{*} & \ldots & 5 & 6 & \ldots & 11 & 42 & \ldots & 6 & 19 & \mathrm{~N} .\end{array}$

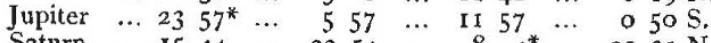

$\begin{array}{llllllllllllllll}\text { Saturn } & \ldots & 15 & 44 & \ldots & 23 & 54 & \ldots & 8 & 4^{*} & \ldots & 22 & 31 & \text { N. }\end{array}$

* Indicates that the rising is that of the preceding and the setting that of the following day.

\section{Occultations of Stars by the Noon}

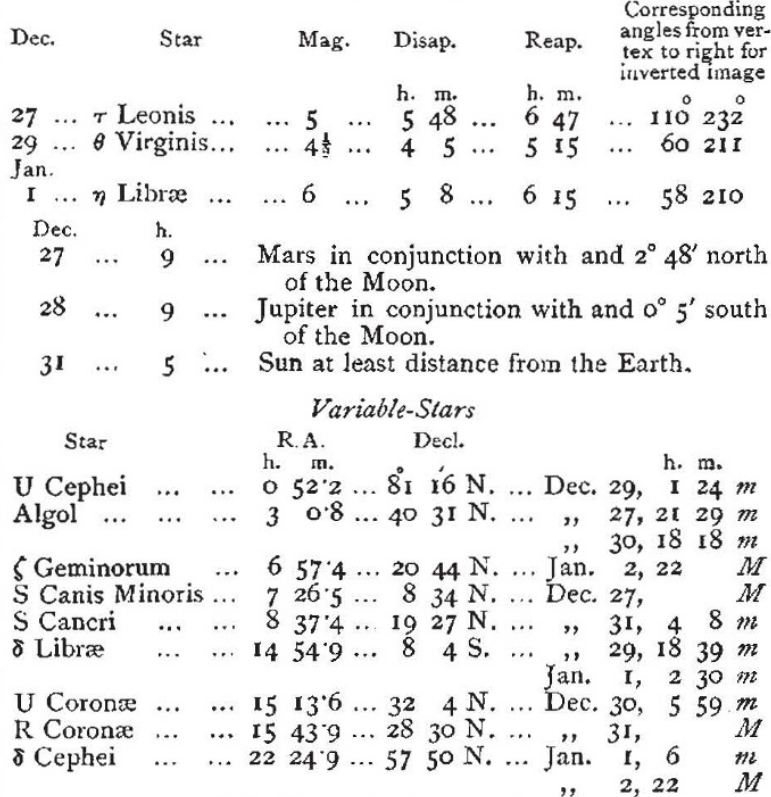

$M$ siguifies maximum ; $m$ minimum.

\section{Meteor Showers}

The principal periodic shower at this time is that of the Quadrantids, R.A. $225^{\circ}-232^{\circ}$, Decl. $55^{\circ}-60^{\circ}$ N., seen on January 2 and 3 . As the radiant-point rises after midnight, the shower must be looked for during the morning hours. A shower with radiant near Aldebaran may be looked for during this week and throughout January.

\section{Stars with Remarkable Spectra}

Mira Ceti, R.A. 2 h. 13m. 36s., Decl. $3^{\circ} 29^{\prime} \cdot 6 \mathrm{~S}$., should be examined with the spectroscope on every favourable opportunity now that it is approaching its maximum. It is a fine example of Secchi's third type.

$$
\text { Star R.A. }{ }^{8866^{\circ}} \text { Decl. } 1886^{\circ} \circ \text { Mag. Type of }
$$

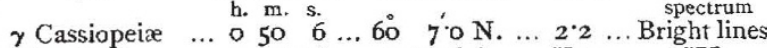

$\begin{array}{lllllllllllll}\text { Mira Ceti ... } & \ldots & 2 & \mathbf{1} 3 & 36 & \ldots & 3 & 29.6 \mathrm{~S} . & \ldots & \text { Var. ... III. }\end{array}$

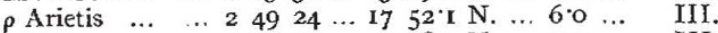

$\begin{array}{lllllllllllllll} & a \\ \text { Ceti... } & \ldots & \ldots & 2 & 51 & 19 & \ldots & 3 & 38.5 & \mathrm{~N} . & \ldots & 2.5 & \ldots & \text { III. }\end{array}$

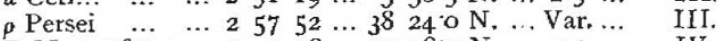

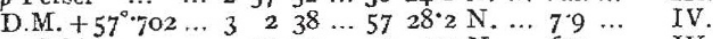

$\begin{array}{llllllllllllllll}5 \text { I Schj. } & \ldots & . . & 4 & 59 & 30 & \ldots & \text { I } & \text { I } 2 & \text { N. } & \ldots & 6 & 6 & \ldots & \ldots & \text { IV. }\end{array}$

20 Leporis...

a Orionis ... $\ldots .554900 .723^{\circ} \mathrm{I}$ N. ... Var.... III.

$\begin{array}{lllllllllllll}\mu \text { Geminorum } & \ldots & 6 & 16 & 3 & \ldots & 22 & 33^{\circ} 6 & \text { N. } & \ldots & 3.0 & \ldots & \text { III }\end{array}$

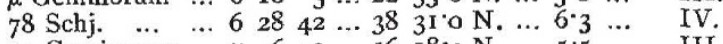

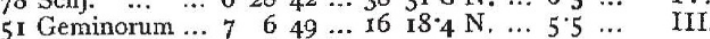

\section{GEOGRAPHICAL, NOTES}

Two papers in the December number of the Proceedings of the Royal Geographical Society are of unusual interest. The first is Mr. F. Simons's account of his exploration of the Goajira peninsula of the United States of Colombia; the second, a series of letters, hitherto unpublished in English, from Colonel Prjevalsky, translated by Mr. Delmar Morgan. Mr. 
Simons first describes the topography of the little-visited peninsula in some detail, and then gives an account of the tribe of Indians inhabiting it, which is of exceeding interest, so remarkable are many of their customs. Their system of compensation - consisting of tear and blood-money, or fines for tears or blood supposed to be shed-is one of the most extraordinary ever found amongst a primitive people, extending not only to injuries, wilful or accidental, done to one man by another, but to accidents happening to a man himself. Every man is a hostage for every one of his clan, and is liable to be called upon to pay various fines for the acts of another; if a man borrows an animal of another and is thrown off, the lender has to pay, first, the relatives of the mother, then the relatives of the father, and, lastly, the friends of the borrower. If a man injures himself he is furced to pay his mother's relations for his own blood which has been spilt, his father's for the tears which they are presumed to have shed, and his friends for the sorrow the accident has caused them, - and all this if he has only cut his finger with bis knife. Many other curious customs are also recorded. Colonel Prjevalsky's letters describe certain clistricts around Lob-Nor, and the route to Cherchen and Kiria. The work of the Admiralty Surveys for 1884 is detailed from the Hydrographer's report. Sir Frederic Goldsmicl writes on the geographical nomenclature if places between Merv and Herat, and Admiral Yrminger, of the Danish Navy, explains, in a letter to the secretary, the so-called subsidence of one of the Faroe Islands, which turns out not to have been a "subsidence" at all.

M. Potanin has again written to the Geographical Society, from Si-nin, under date of April 29. The expedition was continuing its work without the least hindrance, MM. Potanin, Stassy, and Berezovsky exploring the region in all directions, after having wintered in three different towns; the asironomical determinations wcre also made, and the population, far from hindering the surveys, assisted them. A Tangut, in the service of M. Potanin, is a valuable aid in making collections of insects. MM. Potanin and Skassi left San-chuan on April 15, taking a northerly direction to reach the Si-nin River (called Nimbimuren in its lower course). Its valley is inclosed between high walls of loess, and at three different points it is narrowed by crags of gneiss, where some gold is dug. In the Lau-va-sya gorge the limestone crags are covered with numerous and beautiful marmites de geant, one of which has a diameter of I6o centimetres. Above this gorge the valley reaches a width of more than two miles, and two towns, Lau-va-sya and Nimbi, are situated there. They are peopled with Mongols, many of whom are Mussulmans; the villages are peopled with Chinese. $\mathrm{Si}$-nin was reached on April 24, and M. Potanin proposed to leave it soon for Min-cheu, via Gui-Dui, so as to connect his surveys with those of M. Prjevalsky.

THE German Emperor has ordained that the harbour discovered on the north-east coast of Kaiser Wilhelm's Land, north-west of Port Constantine, shall henceforth be known a "Friedrich Wilhelm's Hafen," and the bay near it "Prince Heinrich's Hafen"; the large navigable river discovered east of Cape de la Torre as the "Kaiserin Augusta Fluss," while Beaupré, situated in the middle of the peninsula will now be called "Varzin." "Neu Mecklenburg" will be substituted for New Ireland, "Neu Lauenburg" for the Duke of York group, and "Neu Pommern" for New Britain, the largest island of the Bismarck Archipelago.

THE voyage of the Vega along the north coast of Europe and Asia seems likely to bring about another result, namely, the connection of the Petchora with the Obi by a route presenting fewer clangers than the navigation of the Kara Sea. Thanks to the continuous efforts of MM. Sidoroff and Sibiryakoff, the exploration of the Northern Urals, with a view to discover the best routes for connecting the great river of North-East Russia with the chief artery of Siberia, is being busily prosecuted. It appears now, from a communication by M. Nosiloff to the Russian Geographical Society (Irvestia, iv. 1885), that there are in the Northern Urals passes which would permit of establishing an easy link between the two basins. The best of them seems to be the Schokuriinsk Pass, the same that Prince Kurbsky availed himself of in 1449 to reach the Obi. A portage, only 98 miles Iong, leads from Kuya-a village on the Petchora, within easy reach of steamboats - to the Sygva River, a tributary of the Sosva, which appears to be navigable for boats up to a point distant only 35 miles from the pass over the Ural Mountains. Tha Sygva has a depth of from 4 to 7 feet, and a width of 150 to 350 yards; while the Sosva, 6 to 18 feet cleep, forms an excellent channel for even larger vessels. As to the portage itself, its highest point reaches only 1450 feet above the sea, and 1150 feet above the Sygva; and a railway less than Io miles long would avoid all those difficulties which are now presented by the navigation of the Kara Sea and the ice-bound Gulf of Obi. Another pass, Voikarsky, is at almost the same distance, and its highest point rises about 1650 feet above the sea. The existence of these deeply-indented valleys, and the general configuration of the region, together with the direction of the rivers, once more raises the question, whether the Northern Urals, instead of being one' wincling mountain-chain, are not rather a complex of several smaller chains having a north-easterly direction, and arranged in échelons from south to north. It would be most desirable to have a thorough orographical and geological exploration undertaken in connection with the ahove work, in order to settle one of the most important questions as to the orography of the northern part of the great Russian plain.

WE notice in the last issue of the Izvestia of the Russian Geographical Society (1885, iv.) the following information com. municated by Gen. Meyer with regard to the Transcaspian region. The great ranges of mountains which bear the names of Great and Little Balkhans, Kuren-dagh, and Kopet-dagh, and are continued on the Persian frontier under the names of Asthma, Deireghez, Kelat, and so on, liminish in height towarrls the east, mntil they almost entirely disappear about Saralibs. The chief range reaches, however, 6000 to 7000 feet, with separate peaks 8000 feet high, and the upper parts of its northern slope are covered with snow nearly all the year round. Notwithstanding this, the streams which flow from these mountains into the steppes are remarkably poor; the slates, of which the slopes of the mountains consist, giving the water a free passage into the soil. The ancient inhabitants knew how to utilise this structure of the soil by making their kerizes, or wells, connected together by underground galleries, which, after being dug thus for a mile or two, yielded water for irrigation. These wells are now unfortunately mostly in a bad state, and few of them are of any use. The much-talked-of dams on the Murghab and Heri-rud would not be of great use, as the high water in both rivers comes in the spring, and not in the summer when the fields are most in need of irrigation. The characteristics of the ground are strikingly uniform, a terrace with a soil of dry clay, intersected by small ravines, in all cases spreading at the foot of the mountains. The climate is very dry, but fevers are common, probably in consequence of the very rapid variations of temperature from a hot day to a cold night. At Askabad the yearly average temperature is $24^{\circ} \cdot 8 \mathrm{C}$., the extremes being $3 \mathrm{r}^{\circ} \cdot 5$ and $-8^{\circ} \cdot \mathrm{r}$. Up to a height of $40: 0$ feet the mountains are covered with a steppe flora. Higher up they are mostly quite devoid of vegetation. The artcha, reaching sometimes twenty-five feet, but never growing in forests, is excellent as fuel, but cannot be employed for building. A few willows, poplars, and rushes are sometimes met with along the streams. In the spring the plains are all covered with herbaceous vegetation, which is, however, unfit for pasture. Grazing-grounds are met with only on sandy ground about Akhal. Further east, towards Merv, there are no pasturegrounds, but trees are more numerous. When watered the soil gives good crops: wheat, barley, the Khiva millet, lucerne; cotton and silkworm trees grow well on watered fields, as also poplars, willows, plane-trees, and various kinds of brushwood.

THE following information as to the population of the Trans. caspian region, communicated to the last issue of the Russische Revue ( $\mathbf{8 8 5}$, iv.), by M. Seidlitz, may complete the above. The aggregate population of the region is estimated at from 214,000 to 260 , 000 inhabitants, including Merv-that is, much below previous estimates. The whole region being divided into the districts of Akhal-tekke, Krasnovodsk, Manghishlak, Merv, and Tejen, it appears that the population of the three former districts numbers about 93,000 , who live on agriculture in Akhaltekke and on cattle-breeding in Krasnovodsk and Manghishlak. The agriculture of Akhal-tekke is considerable, the crops of 1883 having yielded no less than 190,000 quarters of wheat, barley, and Sorghum cernumm. The cattle in the three districts are estimated at no less than 44,000 horses, 76,0co camels, and more than 600,000 sheep, to which nearly 130,000 horses, I93,000 camels, and one million and a half of sheep must be added for Merv and Tejen. The culture of cotton and of the silkworm in Akhal-tekke is also worthy of notice. The 
population of Akhal-tekke consists of Tekke-Turcomans (8400 kibitkas, about 42,000 souls), with some II60 Persians and Tartars, 930 Armenians, and 340 Russians, without families. Askabad, the chief town of this district, has already an important trade. The inhabitants of the Krasnovodsk and Manghishlak districts, on the contrary, are nearly all nomads, and their chief towns, Krasnovodsk and Alexandrovsk, are miserable hamlets with less than 400 inhabitants each. The oasis of Merv, with its 32,000 kibitkas, is well peopled. The bazaars of the chief town are very animated, 8000 to 10,000 people gathering there twice a week. Since 1785, when the Sultan-bend dam on the Murghab was destroyed by the Ameer Murad Khan, the area of the oasis has much diminished, and it occupies now only a length of 160 miles, and a width of some 13 miles. The town Bairam-kalæ was abandoned for want of water. The Tekke Turcomans, who have inhabited the oasis since 1857 , when they drove away the Saryks, are divided into two stems, the Okhtamyshs and the Tokhtamyshs. The richer of them live in felt tents, while the poorer ones make huts of clay of the same shape as the felt tents. These settlements and villages are not permanent, and may be changed at the first signal of alarm. In fact the population is too numerous for the watered area. As to the fertile oasis of Tejen, on the Heri-rud, it was formerly visited only in the summer. It has now some 7500 Tekke inhabitants, who have immigrated from Merv, Akhal, and Atek.

Mr. Shipley, the American Consul at Auckland, New Zealand, reports to the State Department at Washington, the following facts about a new volcano in the Pacific Ocean :- "At daylight on October 13 we observed dense volumes of steam and smoke clouds ascending. We sailed sufficiently near to see that it was a submarine volcanic eruption. Considering that it was not prudent to approach any nearer that night, we lay to until morning. We then approached to about a distance of two miles. I have not words to express my wonder and surprise at its changing splendour. Eruptions take place every one or two minutes, changing in appearance every second, like a dissolving view. I can only say that it was one of the most awfully grand sights I ever witnessed on the high seas. As near as I was able to calculate the position of the volcano, it is about fourteen miles from the island of Honga Tonga. As to the size of the island thrown up, I am unable to state it correc:ly, there being so much steam and cloud hanging over it; but I judge it to be at least two or three miles long, and 60 feet high, in lat. $20^{\circ} 2 \mathrm{I}^{\prime} \mathrm{S}$., long. $175^{\circ} 2 \gamma^{\prime} \mathrm{W}$."

\section{THE PARIS ACADEMY OF SCIENCES}

T'HE yearly meeting of the Paris Academy of Sciences took place in the large hall of the Institut on December 2 . Rear-Admiral Julien de la Gravière was in the chair. He read a short paper summarising the eloges of eight members who died during the past twelve months. This number is unusually large in a body of sixty-six.

M. Bertrand delivered two addresses on M. Lagourneria, a geometer, and M. Combes, an engineer, who died some years ago, after having enjoyed the academical honours during many years.

The number of prizes delivered by the Academy is increasing yearly, not less than thirty-three being offered for competition in 1886. The total of the sums to be awarded is more than $3000 \%$, exclusive of some of which the value is to be determined according to the merits of competitors, and the Bréant Prize for a cure for cholera. Dr. Ferran was not even mentioned in the verdict, and the interest of the 4000 l. was given to several writers on the etiology of cholera.

Some of the prizes for 1885 were not awarded, for want of competition, although, except a very few, they are open to every nation, and memoirs can be written in any language as well as in French. A large number of prizes were not delivered for want of merit in the contributions sent. Some of them were awarded to scientific writers who have publıshed volumes on topics connected with the subject-matters. Of this last class we may mention, inler alia, "Memoire sur la Marche et l'Extension du Choléra Asiatique des Indes Orientales," \&c., by Dr. Mahé, representing France at Constantinople; "Contributions à l'Etude de la Fièvre Typhoïde," by Dr. Pietro Santo ; "Statistique de l'Industrie minérale et des Appareils à Vapeur en France et en Algérie," by M. Keller ; "Contributions à l'Etude statistique du Suicide en France," by Dr. Jules Socquct; "Histoire de l'ancienne Académie de Marine de Brest," by M. Donneaud du P'lan, Librarian of the Navy at Dieppe.

Amongst the most important prizes awarded we notice the following :-

M. Amsler Laffon, of Shaffhouse, for his instrument for polar planimetry, as presented by Mr. Scott Russell to the Institution of Naval Architects in 1880 (Monthyon Medallist for Mechanical Arts).

M. Colladon, of Geneva, for the application of compressed air as a motive power in tunnelling Mont Cenis (Fourneyron Medallist).

M. Thollon, for mapping the solar spectrum in the Bischoffsheim Observatory, Nice (Lalande).

Dr. Spörer, of the Potsdam Astro-Physical Observatory, for his studies on solar spots (Voltz).

Dr. Edlund, member of the Academy of Sciences of Stockholm, for his memoir on the origin of electrical tension of the atmosphere. He considers this tension to be produced by the rotation of the earth, which is a magnet. The soil being made negative, the atmosphere becomes positive by induction. The difference of tension resulting from his calculations is 223 volts per kilometre altitude. No less than twelve memoirs were sent -five in French, four in German, and three in English (Boydron Prize). The memoir of Dr. Edlund had been already printed and published.

M. Gernez, for his discoveries in rapid solidification of supersaturated liquids.

M. Halphen, a major in the French Artillery, took the Petit d'Ormay Prize for the ensemble of his mathematical work and principally the solution of the following problem:-Trouver les équations différentielles qui se reproduisent par une substitution linéaire.

The Monthyon Prize for discoveries in connection with unhealthy arts has been given to M. Chamberland, chief assistant of M. Pasteur, who invented a filter in chinaware which stops even microbes.

The Government Prize was given to M. Joannes Chatin for his study of the sensation organs of invertebrate animals.

The Cuvier Medallist for this year is Prof. Van Beneden, of the Louvain University, for half a century of work in physiology.

\section{THE NEW ZEALAND INSTITUTE}

T'HE volume of Transactions of the New Zealand Institute for 1884 was issued to the members in May of the present year. It is edited by Dr. Hector, and contains fifty-five memoirs, which, read before the various affiliated societies, have been deemed worthy, by the Governors of the Institute, of publication. While the papers on biological subjects occupy threefourths of the space devoted to the transactions, those on geology are but few in number. Among the more important of the zoological memoirs may be mentioned the following :- "Descriptions of New Zealand Micro-Lepidoptera," by E. Meyrick (pp. 68-I49). In continuation of his previous memoirs we have here full details and an analysis of the following families :Scopariadæ; while no species of this family is common to New Zealand and Australia, the author has included in his memoir descriptions of the known Australian species of the genera Scoparia, Tetraprosopus and Xeroscopa. Fifty-eight species of the first and sixteen species of the last genus are described. Pyralidæ: Hydrocampidæ; these families are each represented by a single species, neither of which is, in a strict sense, indigenous, Asopia farinalis being introduced from Europe. The representative of the latter family, Hygraula nitens (Butl.), being regarded as a recent migrant from south-east Australia. Pterophoridæ; eleven species are described: one is closely allied to a European form, one is Australian; the other nine are all endemic. In a supplement a number of additions to the previously-published list of species of Crambidæ and Tortricidæe are described. "Further Notes on Coccidæ," by W. M. Maskell. The author comments on our notice this time last year of the roughness of the plates in Vol. XVI. While we agree with him that all biologists are not artists, yet we venture to think that it is not too much to expect that there should be one artist at Wellington who could execute plates in a style worthy not only of the New Zealand Institute, but in keeping with the excellent typography of the volume. Thus, the very "lettering "of the plates in the present volume is not only bad, but misleading, Vol. XIV. being misprinted for Vol. XVII., and Plate 